\title{
Recipes and general herbal formulae in books: causes of herbal poisoning
}

\author{
YK Chong, CK Ching, SW Ng, ML Tse, Tony WL Mak*
}

\section{A B S T R A C T}

Traditional Chinese medicine is commonly used locally, not only for disease treatment but also for improving health. Many people prepare soups containing herbs or herbal decoctions according to recipes and general herbal formulae commonly available in books, magazines, and newspapers without consulting Chinese medicine practitioners. However, such practice can be dangerous. We report five cases of poisoning from 2007 to 2012 occurring as a result of inappropriate use of herbs in recipes or general herbal formulae acquired from books. Aconite poisoning due to overdose or inadequate processing accounted for three cases. The other two cases involved the use of herbs containing Strychnos alkaloids and Sophora alkaloids. These cases demonstrated that inappropriate use of Chinese medicine can result in major morbidity, and herbal formulae and recipes containing herbs available in general publications are not always safe.

\section{Hong Kong Med J 2014;20:343-6}

DOI: $10.12809 / \mathrm{hkmj} 134097$

\author{
${ }^{1}$ YK Chong, MB, BS \\ ${ }^{1}$ CK Ching, FRCPA, FHKAM (Pathology) \\ ${ }^{1} \mathrm{SW} \mathrm{Ng}$, MPhil \\ ML Tse, FHKCEM, FHKAM (Emergency Medicine) \\ ${ }^{1}$ TWL Mak *, FRCPath, FHKAM (Pathology)
}

\author{
Hospital Authority Toxicology Reference Laboratory, Princess Margaret \\ Hospital, Laichikok, Hong Kong \\ 2 Hong Kong Poison Information Centre, United Christian Hospital, \\ Hospital Authority, Hong Kong \\ * Corresponding author: makwl@ha.org.hk
}

\section{Introduction}

Traditional Chinese medicine (TCM) is generally regarded by the public as benign and non-toxic compared with western medications. However, this belief may be untrue. Indeed, herbal poisoning cases are not uncommon locally. ${ }^{1,2}$ Traditional Chinese medicine is often considered by the Chinese as part of a 'healthy' diet to improve the general health. Instead of consulting Chinese medicine practitioners, many people prepare herbal soups or decoctions according to recipes and herbal formulae commonly available in books, magazines, and newspapers. However, the risk of such practice may be under-recognised.

From 2007 to 2012, the Hospital Authority Toxicology Reference Laboratory confirmed five cases of herbal poisoning related to the use of soups or herbal decoctions prepared according to recipes or general herbal formulae acquired from books. We report these cases to highlight the potential danger associated with such practice.

\section{Case reports}

\section{Case 1}

A 77-year-old man with a history of chronic obstructive airway disease and gouty arthritis presented in April 2008 with shortness of breath and generalised numbness. His symptoms started 1 hour after consumption of a herbal decoction prepared from a formula "Frankincense analgesic pill" available in the book "Therapeutics and care for gout". He developed atrial fibrillation and hypotension, and later deteriorated into respiratory failure necessitating intubation and ventilation with intensive care. He also developed multiple episodes of ventricular fibrillation. His condition improved after supportive treatment, and he was discharged 5 days after admission.

Liquid chromatography-tandem mass spectrometry (LC-MS/MS) of herbal remnants and urine specimens showed presence of Aconitum alkaloids (yunaconitine, hypoaconitine, mesaconitine, aconitine). Thus, the patient was diagnosed with severe aconite poisoning. The herbal formula was found to contain two aconite herbs, processed chuanwu $15 \mathrm{~g}$ and caowu $15 \mathrm{~g}$, among other herbs (Table 1). The dosages were 5 times the upper limit of recommended dosages in the 2010 Chinese Pharmacopoeia, ${ }^{3}$ and worse still, it was not mentioned whether caowu in the formula had been processed (Table 2).

\section{Case 2}

A 52-year-old man presented in March 2009 with generalised numbness, weakness, and abdominal pain after taking a herbal decoction prepared from a formula in the book "Excellent prescriptions for one hundred illnesses". He complained of palpitation 


\section{書籍中的食譜和一般草藥配方：中藥中毒的原因 \\ 張耀君、程楚君、吳秀華、謝萬里、麥永禮}

本地使用中國傳統中草藥很普遍, 不僅作治病用途, 也希望藉此改善 健康狀況。很多人在沒有諮詢中醫師的情況下, 根據書籍、雜誌和報 紙提供的食譜和一般草藥配方自製草藥或草藥湯劑。然而, 這種做法 可能很危險。本文報告2007至2012年期間因依據書本內的食譜和草藥 配方而不當使用中草藥的五個中毒病例。其中三例牽涉因過量或不當 處理烏頭類中藥而中毒; 另兩例涉及使用含有馬錢子生物撼和苦參生 物鹼的藥材。這些病例均顯示不適當使用中草藥可導致嚴重後果, 而 從坊間得到的草藥配方和食譜也並不一定安全。 and was found to have ventricular bigeminy. He developed shock shortly afterwards requiring dopamine infusion. His condition improved with supportive management and he was discharged after 3 days.

There were seven herbs in the formula, including processed chuanwu $10 \mathrm{~g}$ and processed caowu $10 \mathrm{~g}$ (Table 1). Aconitum alkaloids (yunaconitine, aconitine, deoxyaconitine, hypaconitine, and mesaconitine) and their hydrolysed products were detected in both urine and herbal remnant samples by LC-MS/MS and gas chromatography-mass spectrometry (GC-MS). The patient was diagnosed with severe aconite poisoning. Contributory factors included a three-fold overdose (Tables 1 and 2), and the concomitant use of two aconite herbs.

\section{Case 3}

A 54-year-old woman presented in November 2007 with a 2-day history of leg cramps, dizziness, sweating, and vomiting. She reported taking "Noodlefish soup" for her knee pain based on a recipe in the book "Cleansing and nourishing soup". She had doubled the doses of all ingredients. She experienced mild leg cramping 2 hours after taking the soup. She reboiled the soup and consumed two doses on the next day; then, she developed bilateral lower limb cramping, tonic contractions, dizziness, nausea, and vomiting. The patient was discharged after 1 day of observation.

In the urine and herbal broth specimens, Strychnos alkaloids (strychnine and brucine) were detected by GC-MS and high-performance liquid chromatography with diode-array detector.

The clinical diagnosis was strychnine poisoning. The recipe contained $9 \mathrm{~g}$ of "maqian" (Table 1), which is a synonym of maqianzi. ${ }^{4}$ The dosage was 15 times higher than the recommended dosage (Table 2).

\section{Case 4}

A 66-year-old man, with multiple medical diseases, presented in February 2012 with hypotension and dizziness 1 hour after consumption of herbal powder prepared according to a "Miraculous bone-setting formula" available in the book "Compilation of secret formulae from the Shaolin temple". He required fluid resuscitation and was discharged on the second day. In the herbal powder and urine sample,

TABLE I. Herbal formulae or recipes involved in the poisoning cases

\begin{tabular}{|c|c|c|}
\hline Case No. & Name of book and publisher & Herbal formulae/recipes (prepare as decoction unless otherwise stated) \\
\hline 1 & $\begin{array}{l}\text { 星輝醫療保健系列9 一一痛風症治療與護理 } \\
\text { (Therapeutics and care for gout) } \\
\text { 王方凌 / 星輝圖書有限公司 }\end{array}$ & $\begin{array}{l}\text { Frankincense analgesic pill (乳香定痛丸) } \\
\text { - Radix Aconiti Praeparata (processed chuanwu, 製川烏) 五錢( } 15 \mathrm{~g}) \text {, Radix Aconiti } \\
\text { Kusnezoffii (caowu,草烏) 五錢 }(15 \mathrm{~g}) \text {, Arisaema Cum Bile (dannanxing, 膽南星) 三錢 } \\
\text { ( 9 g), Pheretima (dilong, 炒地龍) 二錢 }(\sim 6 \mathrm{~g}), \text { Olibanum (ruxiang, 乳香) 四錢 }(\sim 2 \mathrm{~g}) \text {, } \\
\text { Myrrh (moyao, 沒藥) 四錢( 12 g) }\end{array}$ \\
\hline 2 & $\begin{array}{l}\text { 百病良方 (Excellent prescriptions for one } \\
\text { hundred illnesses) } \\
\text { 人民軍醫出版社 }\end{array}$ & $\begin{array}{l}\text { - Radix et Rhizoma Asari (xixin, 細辛) } 10 \mathrm{~g} \text {, Herba Ephedrae (mahuang, 麻黃) } 6 \\
\text { g, Radix Aconiti Praeparata (processed chuanwu, 製川烏) } 10 \mathrm{~g} \text {, Radix Aconiti } \\
\text { Kusnezoffii Praeparata (processed caowu, 製草烏) } 10 \mathrm{~g} \text {, Radix Angelicae Sinensis } \\
\text { (danggui, 當歸) } 12 \mathrm{~g} \text {, Rhizoma Atractylodis Macrocephalae (baizhu, 白術) } 12 \mathrm{~g} \text {, } \\
\text { Radix Stephaniae Tetrandrae (hanfangji, 漢防己) } 15 \mathrm{~g}\end{array}$ \\
\hline 3 & $\begin{array}{l}\text { 清潤湯水 (Cleansing and nourishing soup) } \\
\text { 李南 / 勤+緣出版社 }\end{array}$ & $\begin{array}{l}\text { Noodlefish soup (白飯魚湯) } \\
\text { - Noodlefish, ginger, spare ribs, Radix Dipsaci (chuanxuduan, 川續斷) 五錢( 15 g), } \\
\text { Rhizoma Cibotii (jingouji, 金狗脊) 五錢 ( 15 g), maqian (馬前) 三錢( 9 g) [dispensed } \\
\text { as Semen Strychni (maqianzi, 馬錢子) 三錢( 9 g)] }\end{array}$ \\
\hline 4 & $\begin{array}{l}\text { 少林寺武術傷科秘方集釋 (Compilation of } \\
\text { secret formulae from the Shaolin temple) } \\
\text { 韋以宗 主編 / 上海科學技術出版社 }\end{array}$ & $\begin{array}{l}\text { Miraculous bone-setting formula (神效接骨奇方) } \\
\text { - Radix Angelicae Sinensis (danggui, 當歸) 三錢( 9 g), Radix Angelicae Dahuricae } \\
\text { (baizhi, 白芷) 三錢( 9 g), Radix Aconiti Kusnezoffii (caowu, 草烏) 三錢 }(\sim 9 \mathrm{~g}) \\
\text { - Instructions: Pulverise and mix the above raw herbs, then consume 二錢 }(\sim 6 \mathrm{~g}) \text { of the } \\
\text { herbal powder mix dissolved in wine without decoction }\end{array}$ \\
\hline 5 & $\begin{array}{l}\text { 四季湯水篇 (Soup for four seasons) } \\
\text { 李南 / 博益出版集團有限公司 }\end{array}$ & 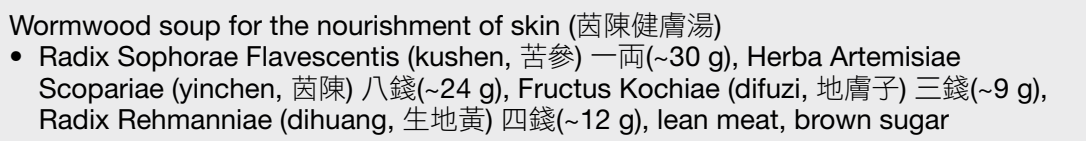 \\
\hline
\end{tabular}


Aconitum alkaloids (aconitine, mesaconitine, hypaconitine, yunaconitine, and deoxyaconitine) and their hydrolysed products were detected by GC-MS and LC-MS/MS. The diagnosis was moderate aconite poisoning. The formula was found to contain caowu and two other herbs (Tables 1 and 2). According to the instruction, the patient pulverised and mixed $9 \mathrm{~g}$ of each of the three herbs, and then consumed $6 \mathrm{~g}$ of the mixed herbal powder dissolved in wine without decoction. Although the actual dose of caowu consumed ( $2 \mathrm{~g}$ ) was within the recommended dosage, the herb was not intended for internal use before prolonged decoction to hydrolyse the toxic Aconitum alkaloids.

\section{Case 5}

A 40-year-old woman presented in October 2009 with nausea, vomiting, dizziness, and sweating 50 minutes after taking a bowl of soup prepared from a recipe "Wormwood soup for the nourishment of skin" in the book "Soup for four seasons" for her skin rash. The ingredients of the recipe included kushen $30 \mathrm{~g}$ among other ingredients (Table 1). Neurological examination was unremarkable. Clinically, matrine poisoning was suspected. After 4 hours of observation, her symptoms improved and she was discharged.

The herbal remnant and urine samples were found to contain Sophora alkaloids (matrine, sophoridine, cytisine, and N-methylcytisine) by GC-MS. The diagnosis was matrine poisoning. The dosage of kushen in the recipe was 3 times higher than the upper limit of recommended dosage (Table 2). ${ }^{3}$

\section{Discussion}

In the Chinese culture, medicine and food are considered one inseparable entity. It is very common for the Chinese to add medicinal herbs in their soups and dishes to achieve different goals-prevention of illness, treatment of disease, and nourishment of the body. Rather than consulting a Chinese medicine practitioner, it is not uncommon for the Chinese to prepare herbal decoctions or soups according to formulae or recipes in newspapers, magazines, or books. The risk associated with such practice, however, may be under-recognised, as illustrated by our cases.

Three of the five cases (cases 1, 2, and 4) reported here were related to the use of aconite herbs, which are frequently used in TCM for their antiinflammatory and analgesic properties. However, aconite herbs are toxic with low therapeutic indices, and processing and prolonged decoction are necessary before internal use. Aconite poisoning, characterised by limb and perioral numbness, arrhythmia, hypotension and gastro-intestinal disturbances, is the most common cause of severe herbal poisoning locally. ${ }^{5}$ Our group has previously summarised the clinical features of 52 cases of aconite poisoning. ${ }^{1}$ Concerning the three cases reported here, overdose was the cause of poisoning in two cases, whereas the use of herbs without prior decoction accounted for poisoning in the third one.

The issue of overdosing is further illustrated by case 5 , in which overdose of kushen (3 times the recommended dose) was identified as the cause of matrine poisoning. Sophora alkaloids, present in the herb kushen, are known to cause dizziness, nausea,

TABLE 2. Prescribed dosages of toxic herbs implicated in the five cases and the corresponding recommended dosages in 2010 Chinese Pharmacopoeia

\begin{tabular}{|c|c|c|c|}
\hline Case & Herb & Prescribed dosage (daily) & Recommended dosage $^{3}$ (daily) \\
\hline \multirow[t]{2}{*}{1} & $\begin{array}{l}\text { Processed chuanwu (製川烏) } \\
\text { [Radix Aconiti Praeparata] }\end{array}$ & $\begin{array}{l}\sim 15 \mathrm{~g} \\
5 \mathrm{x} \text { overdose }\end{array}$ & $1.5-3 \mathrm{~g}$ \\
\hline & $\begin{array}{l}\text { Caowu (草烏) } \\
\text { [Radix Aconiti Kusnezoffii] (not specified as } \\
\text { processed or unprocessed herb) }\end{array}$ & $\begin{array}{l}\sim 15 \mathrm{~g} \\
5 \mathrm{x} \text { overdose }\end{array}$ & $\begin{array}{l}\text { Processed caowu: } 1.5-3 \mathrm{~g} \\
\text { Unprocessed caowu: not for internal use }\end{array}$ \\
\hline \multirow[t]{2}{*}{2} & $\begin{array}{l}\text { Processed chuanwu (製川烏) } \\
\text { [Radix Aconiti Praeparata] }\end{array}$ & $\begin{array}{l}10 \mathrm{~g} \\
>3 \mathrm{x} \text { overdose }\end{array}$ & $1.5-3 \mathrm{~g}$ \\
\hline & $\begin{array}{l}\text { Processed caowu (製草烏) } \\
\text { [Radix Aconiti Kusnezoffii Praeparata] }\end{array}$ & $\begin{array}{l}10 \mathrm{~g} \\
>3 \times \text { overdose }\end{array}$ & $1.5-3 \mathrm{~g}$ \\
\hline 3 & $\begin{array}{l}\text { Maqianzi (馬錢子) } \\
\text { [Semen Strychni] }\end{array}$ & $\begin{array}{l}\sim 9 \mathrm{~g} \\
15 \mathrm{x} \text { overdose }\end{array}$ & $0.3-0.6 \mathrm{~g}$ \\
\hline 4 & $\begin{array}{l}\text { Caowu (草烏) } \\
\text { [Radix Aconiti Kusnezoffii] (not specified as } \\
\text { processed or unprocessed herb) }\end{array}$ & $\begin{array}{l}\sim 2 \mathrm{~g} \\
\text { (dissolved in wine without decoction) }^{*}\end{array}$ & $\begin{array}{l}\text { Processed caowu: } 1.5-3 \mathrm{~g} \\
\text { Unprocessed caowu: not for internal use }\end{array}$ \\
\hline 5 & $\begin{array}{l}\text { Kushen (苦參) } \\
\text { [Radix Sophorae Flavescentis] }\end{array}$ & $\begin{array}{l}\sim 30 \mathrm{~g} \\
>3 \mathrm{x} \text { overdose }\end{array}$ & $4.5-9 \mathrm{~g}$ \\
\hline
\end{tabular}

* Prolonged decoction of processed caowu is generally required before internal use 
and vomiting. ${ }^{6}$ Neurological toxicity has also been reported in severe cases.

The cause of strychnine poisoning in case 3 was traced to a typesetting error in the book; the text said "maqian" instead of "mati" (water chestnut). This was confirmed by crosschecking with the same recipe in another book by the same author. Severe strychnine poisoning can cause muscle twitching, convulsions, rhabdomyolysis, and even death. Despite doubling the dose of all herbs in the soup with a 15 times higher dose of maqianzi, the clinical toxicity of the patient was relatively mild. It could be related to the fact that maqianzi was not pulverised and remained intact after boiling.

The chain of events leading to clinical poisoning in these cases reflects failure of multiple parties in practising safe use of Chinese herbs. The authors should exercise careful judgement in choosing safe herbal formulae or recipes for inclusion in their books, and there should be adequate quality control by editors, especially to prevent typographic errors that can lead to grave consequences. The general public should be educated that Chinese medicine is not always benign and safe, and consulting a Chinese medicine practitioner before taking herbs is always advisable.

The fact that gross overdoses of herbs were being dispensed from the herbal shops also played a role in these poisoning cases. Currently, except the Schedule 1 Chinese medicines, no guideline exists in Hong Kong on the maximum dosage of a particular herb, including the toxic processed aconite herbs, above which one cannot dispense. Of note, the dosages dispensed in these cases were well above the dosage recommended in the Chinese Pharmacopoeia. ${ }^{7}$ We believe that the availability of such guidelines will serve to improve the safety of TCM.

Awareness and knowledge of common herbal poisoning among clinicians can allow correct diagnosis and timely treatment of the poisoned patients. Laboratory analyses of the herbal samples and biological samples can help to confirm the diagnosis.

\section{Conclusion}

The five unfortunate cases in this series illustrate that inappropriate use of Chinese medicine can result in significant morbidity. General herbal formulae and recipes containing herbs are not always safe. Enhancing the standards of these publications, improving the practice of dispensing herbs, and public education on the safe use of Chinese medicine will, hopefully, prevent similar cases from happening again.

\section{References}

1. Chen SP, Ng SW, Poon WT, et al. Aconite poisoning over 5 years: a case series in Hong Kong and lessons towards herbal safety. Drug Saf 2012;35:575-87.

2. Cheng KL, Chan YC, Mak TW, Tse ML, Lau FL. Chinese herbal medicine-induced anticholinergic poisoning in Hong Kong. Hong Kong Med J 2013;19:38-41.

3. State Pharmacopoeia Commission. Chinese Pharmacopoeia 2010. Volume I. Beijing, China: Chemical Industry Press; 2010.

4. State Administration of Traditional Chinese Medicine; the editorial committee of Chinese Materia Medica. China: Shanghai Science and Technology Press; 1999.

5. Chan TY, Chan JC, Tomlinson B, Critchley JA. Chinese herbal medicines revisited: a Hong Kong perspective. Lancet 1993;342:1532-4.

6. Drew AK, Bensoussan A, Whyte IM, Dawson AH, Zhu X, Myers SP. Chinese herbal medicine toxicology database: monograph on Radix Sophorae Flavescentis, "ku shen". J Toxicol Clin Toxicol 2002;40:173-6.

7. Hong Kong Special Administrative Region Government. Chinese Medicine Ordinance (Cap 549, Laws of Hong Kong); 2010. 